\title{
RFRP neurons are critical gatekeepers for the photoperiodic control of reproduction
}

\section{Valérie Simonneaux* and Caroline Ancel}

Neurobiologie des Rythmes, Institut des Neurosciences Cellulaires et Intégratives, UPR CNRS 3212, Strasbourg, France

\section{Edited by: \\ Hubert Vaudry, University of Rouen, France}

Reviewed by:

Lance Kriegsfeld, University of

California, USA

lain J. Clarke, Monash University, Australia

\section{*Correspondence:}

Valérie Simonneaux, Neurobiologie des Rythmes, Institut des

Neurosciences Cellulaires et Intégratives, UPR CNRS 3212 ,

5, rue Blaise Pascal, 67084

Strasbourg, France.

e-mail: simonneaux@inci-cnrs. unistra.fr

\begin{abstract}
Seasonally breeding mammals rely on the photoperiodic signal to restrict their fertility to a certain time of the year. The photoperiodic information is translated in the brain via the pineal hormone melatonin, and it is now well-established that it is the variation in the duration of the nocturnal peak of melatonin which synchronizes reproduction with the seasons. The Syrian hamster is a long day breeder, and sexual activity is therefore promoted by exposure to a long day photoperiod and inhibited by exposure to a short day photoperiod. Interestingly, in this species electrolytic lesion of the mediobasal hypothalamus abolishes the short day-induced gonadal regression. We have shown that the expression of a recently discovered neuronal population, namely RFamide-related peptide (rfrp) neurons, present in the mediobasal hypothalamus, is strongly down-regulated by melatonin in short day conditions, but not altered by circulating levels of sex steroids. The role of rfrp and its product RFRP-3 in the regulation of reproductive activity has been extensively studied in mammals, and our recent findings indicate that this peptide is a potent stimulator of the reproductive axis in the Syrian hamster. It induces a marked increase in $\mathrm{GnRH}$ neuron activity and gonadotropin secretion, and it is able to rescue reproductive activity in short day sexually inactive hamsters. Little is known about the localization of the RFRP-3 receptor, GPR147, in the rodent brain. Accumulating evidence suggests that RFRP-3 could be acting via two intermediates, the GnRH neurons in the preoptic area and the Kiss 1 neurons in the arcuate nucleus, but future studies should aim at describing the localization of Gpr147 in the Syrian hamster brain. Altogether our data indicate that the rfrp neuronal population within the mediobasal hypothalamus might be a serious candidate in mediating the photoperiodic effects of melatonin on the regulation of the reproductive axis.
\end{abstract}

Keywords: RFamide peptide, RFRP-3, GPR147, kisspeptin, seasonal reproduction, melatonin
MAMMALS USE THE RHYTHMIC SECRETION OF THE PINEAL HORMONE MELATONIN TO SYNCHRONIZE REPRODUCTION WITH THE SEASONS

A large number of species restrict their fertility to a particular time of the year to ensure that the birth of the offspring occurs during the most favorable season. To determine the time of the year and synchronize their reproductive activity accordingly, mammals use the highly reproducible annual variations in light duration (or photoperiod). Photoperiod is transduced by a photoneuroendocrine system composed of the retina, the suprachiasmatic nucleus (seat of the master circadian clock) and the pineal gland which releases the hormone melatonin exclusively at night, so that the duration of the secretion varies according to night length. Therefore, the photoperiodic variations in circulating levels of melatonin throughout the year provide the body with a robust and reproducible representation of the seasons (Simonneaux and Ribelayga, 2003). It has long been established that photoperiodic variations in the duration of the nocturnal peak of melatonin synchronize reproduction in seasonal species like sheep or hamsters (Hoffman and Reiter, 1965; Carter and Goldman, 1983; Pevet, 1988; Bartness et al., 1993; Malpaux et al., 2001).

Syrian hamsters are long day breeders, meaning that they are sexually active in long day (LD: 14 light/10 h dark) conditions.
Upon exposure to short day (SD: 10 light/14 h dark) conditions, they undergo a dramatic inhibition of reproductive activity within $8-10$ weeks manifested by a marked atrophy of the gonads and accessory organs resulting in low levels of circulating sex steroids. Surgical removal of the pineal gland before exposure to SD conditions prevents hamsters from undergoing sexual inactivation. Conversely, exogenous melatonin injections mimicking SD conditions in hamsters raised in LD conditions induce sexual inactivation. In contrast to small rodents, large mammals with a longer gestation time like sheep are SD-breeders; they are sexually active in SD conditions and become quiescent after transfer to LD conditions. Although the reproductive timing is opposite in hamsters and sheep, in both cases the circulating levels of melatonin synchronize reproduction with photoperiod. However, why the reproductive systems of LD- and SD-breeders respond in opposite ways to the same melatonin signal is not known.

\section{MELATONIN ACTS ON THE PARS TUBERALIS TO TRANSMIT PHOTOPERIODIC INFORMATION}

It is clear that melatonin does not act directly on GnRH neurons and responsiveness to GnRH does not change with photoperiod (Urbanski et al., 1991). Melatonin binding sites are found 
in a number of brain structures but with considerable species differences (Masson-Pevet et al., 1994). Besides, a high density of melatonin receptors has been identified in the pars tuberalis of the adenohypophysis in a large number of mammalian species (Masson-Pevet and Gauer, 1994). Notably, the pars tuberalis cells expressing melatonin receptors synthesize thyroid-stimulating hormone (TSH) in a photoperiod/melatonin-dependent manner, with a higher level of expression in LD conditions (Klosen et al., 2002; Dardente et al., 2003, 2010). TSH produced by the pars tuberalis has been recently recognized as a key messenger through which melatonin acts on the gonadotropic axis for the seasonal control of reproduction. TSH acts on a specialized glial cell type of the hypothalamic ependymal wall, the tanycytes, to induce a marked up-regulation of the thyroid hormone-activating enzyme deiodinase 2 (Dio2) which in turn increases local concentrations of the bioactive T3 thyroid hormone (Yoshimura et al., 2003; Hanon et al., 2008, 2010; Nakao et al., 2008). In quail (Yoshimura et al., 2003) and Siberian hamsters (Barrett et al., 2007) local T3 administration was reported to increase reproductive activity although through unknown mechanisms.

Altogether these observations point to the pars tuberalis as a key site for the integration of the endocrine melatoninergic message for the seasonal regulation of reproductive activity. However, the central reproductive site(s) actually controlled by the melatonin/TSH system is(are) still unknown. Various structures in the mediobasal hypothalamus have been proposed to be direct or indirect sites of action for melatonin, particularly in the sheep (Malpaux et al., 1998) and hamster (Maywood and Hastings, 1995).

\section{RFRP-3 NEURONS LOCATED IN THE MEDIOBASAL HYPOTHALAMUS ARE STRONGLY REGULATED BY MELATONIN}

In the Syrian hamster, the dorsal part of the mediobasal hypothalamus appears as a key structure for the photoperiodic regulation of reproductive activity since it contains melatonin binding sites and its ablation by electrolytic lesion prevents the inhibitory effect of melatonin on reproductive activity (Maywood et al., 1996). Recently, we reported that neurons located in this hypothalamic area express the RFamide-related peptide ( $r f r p$ ) gene in a photoperiodic-dependent manner in Siberian and Syrian hamsters (Revel et al., 2008).

The rfrp gene was discovered in 2000 in mammals (Hinuma et al., 2000), concurrently with the discovery of its avian ortholog gonadotropin-inhibitory hormone (gnih; Tsutsui et al., 2000). The $r f r p$ and gnith genes were found to produce new peptides of the RFamide family of peptides, which share a common C-terminal LPXRFamide (X = L or Q) motif. In the quail, GnIH was shown to act directly at the level of the pituitary to inhibit gonadotropin release (Tsutsui et al., 2000). In mammals, the rfrpgene is expressed in neurons located in the mediobasal hypothalamus and encodes a precursor that produces two peptides, RFRP-1 and RFRP-3 (Ukena and Tsutsui, 2001; Kriegsfeld et al., 2006; Clarke et al., 2008; Dardente et al., 2008; Revel et al., 2008; Smith et al., 2008; Rizwan etal., 2009). The demonstration that $\mathrm{GnIH}$ is a potent inhibitor of gonadotropin release in birds spurred great interest in the roles of RFRP-1 and particularly RFRP-3 in the regulation of endocrine functions in mammals (Bentley et al., 2010;
Kriegsfeld et al., 2010; Smith and Clarke, 2010; Tsutsui et al., 2010 for reviews).

In Syrian and Siberian hamsters, we observed that the level of $r f r p$ mRNA is strongly down-regulated in sexually inactive SDadapted animals (Revel et al., 2008). This variation is solely photoperiodic as there are no daily changes in rfrp mRNA levels either in LD or SD conditions. In both species, the SD-induced decrease in rfrp gene expression is associated with a similar decrease in peptide immunoreactivity in perikarya and fibers (Revel et al., 2008; Mason et al., 2010; Ubuka et al., 2012; Figure 1). We have recently found a similar SD-induced inhibition of $r f r p$ expression in other LD-breeders, notably the European hamster (Figure 1) and the jerboa (Janati et al., 2012). Strikingly, in sheep, a SD-breeder, two studies reported that hypothalamic $r f r p$ mRNA levels and RFRP immunoreactivity are also reduced in SD conditions while animals are sexually active (Dardente et al., 2008; Smith et al., 2008). In contrast, in the non-photoperiodic rat $r f r p$ mRNA levels are not modified by photoperiodic conditions (Revel et al., 2008).

In the Syrian hamster, we demonstrated that the SD downregulation of $r f r p$ expression is not due to the lower levels of

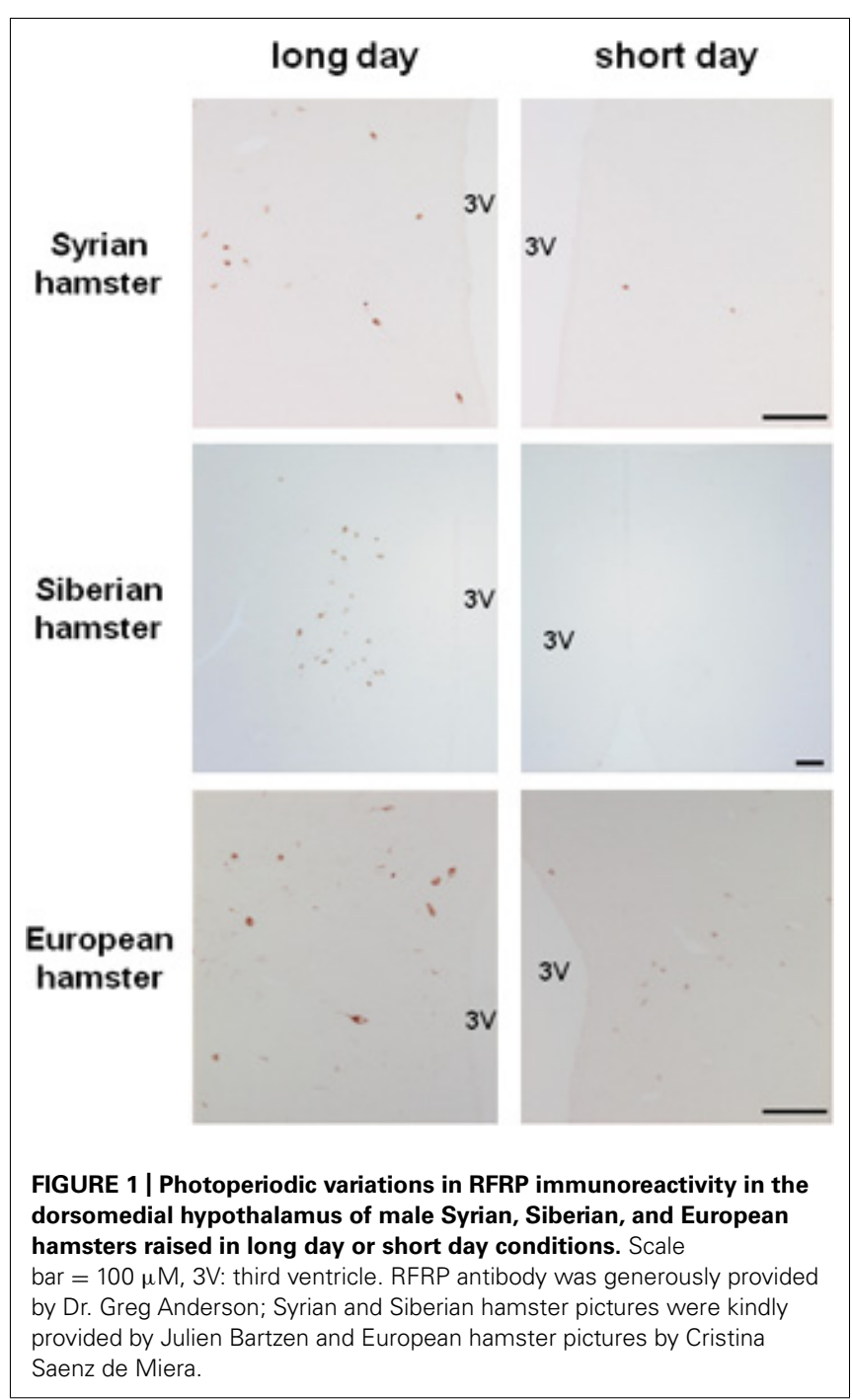


circulating sex steroids since neither testosterone implants in sexually inactive SD hamsters, nor testis ablation in LD-adapted hamsters altered the levels of $r f r p$ mRNA. This lack of major sex steroid feedback on $r f r p$ expression is in agreement with other studies conducted in rats, mice, Siberian hamsters, and sheep (Smith et al., 2008; Quennell et al., 2010; Poling et al., 2012; Ubuka et al., 2012). Of note however, studies in female Syrian hamsters reported that RFRP neurons contain Er- $\alpha$ and respond to estrogen administration (Kriegsfeld et al., 2006; Gibson et al., 2008) and RFRP expression in ewe is reduced during the preovulatory period (Clarke et al., 2012).

Importantly, we found that pineal gland ablation before transferring hamsters to SD conditions, a protocol which prevents the SD-induced inhibition of reproductive activity, prevented the decrease in rfrp mRNA levels (Revel et al., 2008). Conversely, repeated melatonin injections during the late afternoon to LD-adapted hamsters, a protocol known to inhibit reproductive activity, also induced a marked decreased in rfrp mRNA levels (Revel etal., 2008). In the Siberian hamster as well, the down-regulation of $r f r p$ expression in SD conditions is induced by melatonin (Ubuka etal., 2012). Remarkably, in the quail, melatonin also regulates $\mathrm{GnIH}$ expression but in an opposite manner compared to mammals. Melatonin binds to Mel1c receptors located on GnIH neurons to increase GnIH synthesis and release, and as a consequence, expression of this inhibitory peptide is increased under SD conditions (Ubuka et al., 2005).

Altogether these observations indicate that in a number of seasonal mammalian species, $r f r p$ expression is decreased in SD conditions regardless of whether the species is a $\mathrm{LD}$ - or a SDbreeder. Experiments with melatonin manipulation carried out in Syrian and Siberian hamsters demonstrate that rfrp downregulation results from the larger production of melatonin in SD conditions. It is tempting to speculate that melatonin may act primarily on RFRP neurons in the mediobasal hypothalamus to control seasonal reproduction. Several observations, however, indicate that this central effect of melatonin is probably indirect. Melatonin binding sites are found in the area where RFRP neurons are located in the Syrian hamster, but this is not the case in the other seasonal species like the Siberian and European hamsters or the sheep. Furthermore, in the Syrian hamster, we found that at least 3 weeks of daily melatonin administration is required to induce a significant reduction in the level of $r f r p$ mRNA (Revel et al., 2008) whereas the pineal hormone is much faster to control the expression of other photoperiodically regulated genes like $t s h$ in the pars tuberalis or deiodinase 2 in the tanycytes (Revel et al., 2006a; Yasuo et al., 2007; Dardente, 2012). Therefore, it appears likely that there is an intermediate between the endocrine melatoninergic message and the photoperiodic regulation of RFRP expression, and it might be interesting to investigate whether it is the melatonin-driven TSH/T3 signal.

\section{RFRP-3 STIMULATES THE GONADOTROPIC AXIS AND RESCUES REPRODUCTIVE ACTIVITY IN PHOTO-INHIBITED HAMSTERS}

An increasing number of studies now indicate that RFRP3 is implicated in the regulation of mammalian reproductive function (Bentley et al., 2010; Tsutsui et al., 2010 for reviews).
In mice RFRP-3 was found to exhibit rapid and repeatable inhibitory effects on the firing rate of a subpopulation of $\mathrm{GnRH}$ neurons (Ducret etal., 2009). In male rats, intracerebroventricular (icv) RFRP-3 significantly suppresses all facets of sex behavior and also significantly reduces plasma levels of luteinizing hormone (LH; Johnson etal., 2007; Pineda et al., 2010). In female rats, chronic icv infusion of RFRP-3 causes a dosedependent inhibition of GnRH neuronal activation at the LH surge peak and also suppresses neuronal activation in the anteroventral periventricular region, which provides stimulatory input to GnRH neurons (Anderson et al., 2009). In ovariectomized mature rats, intravenous administration of RFRP-3 significantly reduces plasma LH concentrations (Murakami etal., 2008). Finally, in the ovine and bovine species, RFRP-3 administration inhibits gonadotropin release (Clarke et al., 2008; Kadokawa et al., 2009; Sari et al., 2009) although this is still controversial (Caraty et al., 2012).

Until recently, and based on the plethora of publications supporting this hypothesis, it was assumed that RFRP-3 functioned in mammals as GnIH functioned in birds and served as an inhibitory component regulating the hypothalamic-pituitarygonadal axis. However, this statement was somehow contradictory with our observation of an increased synthesis of RFRP in LDadapted sexually active hamsters. We have recently reported novel findings in the male Syrian hamster (Ancel et al., 2012) which have led to call this assumption into question, concurrently with another group working on the male Siberian hamster (Ubuka et al., 2012). In the male Syrian hamster, we reported that acute icv administration of RFRP-3 stimulates $\mathrm{GnRH}$ cell activity, gonadotropin release, and testosterone production under LD conditions (Figure 2; Ancel et al., 2012). In the same manner, in SD-adapted male Syrian hamsters a single central injection of RFRP-3 increases gonadotropin release $[\mathrm{LH}(\mathrm{ng} / \mathrm{ml})$ vehicle $1.72 \pm 0.31$ vs. RFRP-3 $4.36 \pm 0.82 ; n=6$; $p<0.05]$. Furthermore, under the same photo-inhibitory conditions, 5 weeks of continuous central administration of RFRP-3 to male Syrian hamsters produces a complete reactivation of the reproductive axis, manifested by increased testis weight and circulating levels of testosterone, similar to those observed in LD conditions (Figure 3A; Ancel et al., 2012). In the Siberian hamster, while administration of RFRP-3 in LD conditions inhibits gonadotropin release, the same protocol stimulates gonadotropin secretion in SD conditions (Ubuka et al., 2012). Remarkably, these findings of a stimulatory action of RFRP-3 on the male hamster reproductive axis are in sharp contrast with a previous study reporting an inhibitory effect of icv GnIH in ovariectomized female Syrian hamsters (Kriegsfeld et al., 2006). In LD conditions, reproductive activity of female rodents displays a well-described estrous cycle, characterized by varying levels of circulating gonadotropins and sex steroids. It has been hypothesized that RFRP-3 might be an inhibitory component of the negative feedback loop which regulates the estrous cycle, since RFRP cellular activity is decreased at the time of the LH surge in the Syrian hamster (Gibson et al., 2008). In this context it would be interesting to determine whether the effect of RFRP-3 on the female reproductive axis depends on the stage of the estrous cycle at which it is administered. 

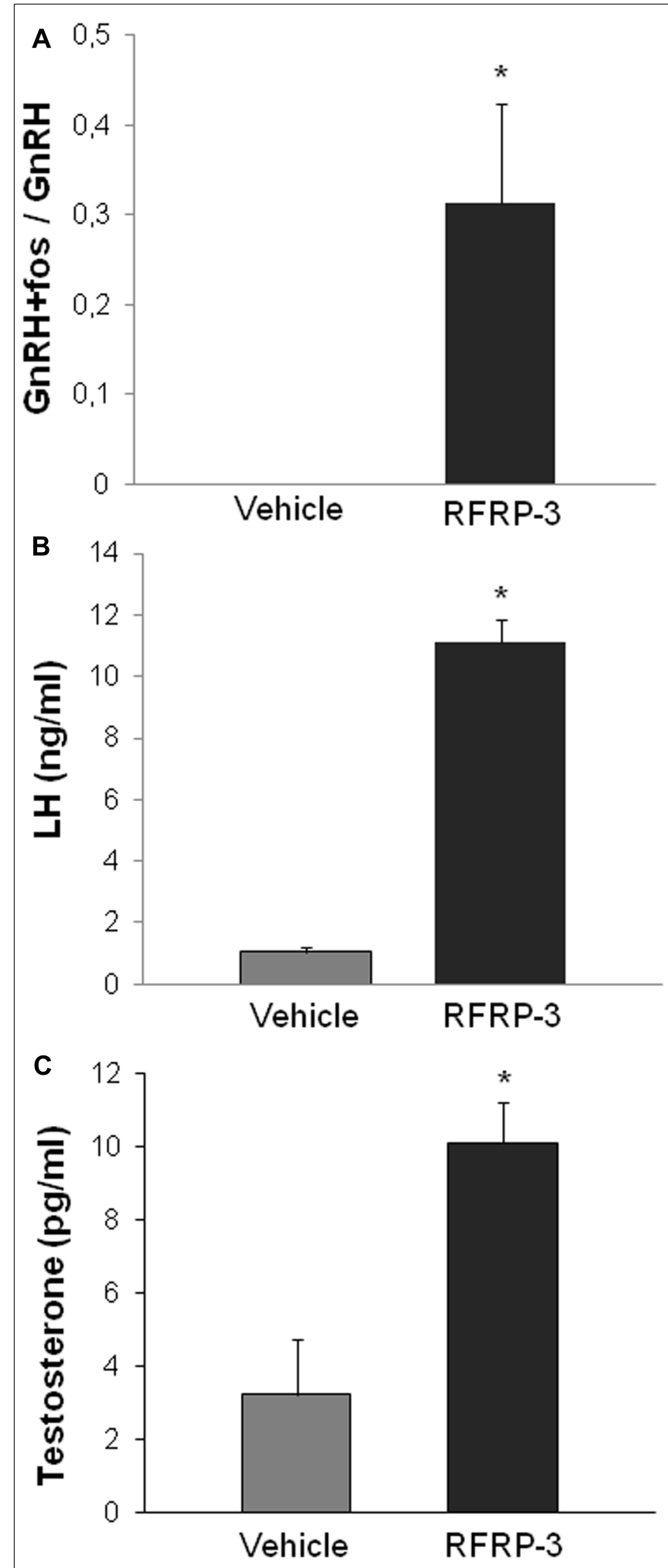

FIGURE 2 | Acute intracerebroventricular administration of RFRP-3 (1500 ng) activates c-FOS expression in GnRH neurons (A) and increases $\mathrm{LH}$ production (B) and circulating levels of testosterone (C) in sexually active long day-adapted male Syrian hamsters. ${ }^{*} p<0.05$ when compared to vehicle-treated animals. Adapted from Ancel et al. (2012).

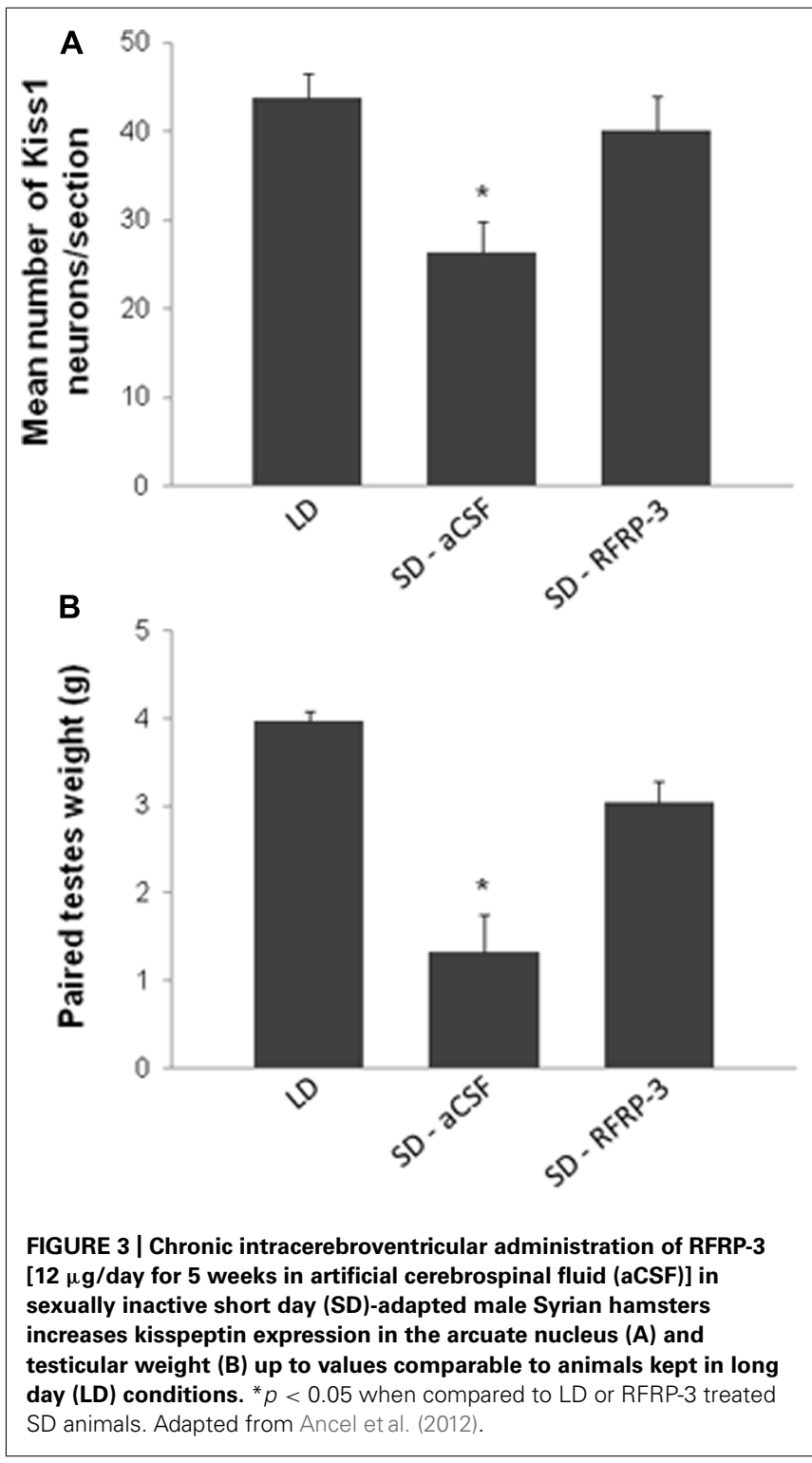

Taken together, these data indicate that there are certainly species- and gender-dependent differences in the involvement of RFRP-3 in the regulation of reproductive activity. As a consequence one might be cautious when calling the mammalian peptide "GnIH" based on its effect in birds, and in the light of the recent reports on work carried out in male hamsters the peptide should be termed "RFRP-3." From a seasonal point of view, when considering LD- (hamster) and SD- (sheep) breeders, it is remarkable to find that while the expression of the peptide in increased in LD conditions in both kinds of breeders, the effect of the peptide on the gonadotropic axis is opposite, as it is stimulatory in hamsters and inhibitory in sheep. This suggests a non-conserved role and/or site of action for RFRP-3 across seasonally breeding species. It is tempting to speculate that RFRP neurons may play a key role in discriminating between long and short day breeders because RFRP expression is down-regulated by a short day profile of melatonin in both kinds of seasonal breeders but the peptide appears to 
have an opposite effect on the reproductive axis, being stimulatory in long day and inhibitory in short day breeders. Complementary experiments will have to be carried out in other species to test this hypothesis and fully understand the role of RFRP-3 in the seasonal control of reproduction.

Interestingly, the RFRP peptides were shown to have a modulatory action on feeding behavior (Bechtold and Luckman, 2007; Johnson et al., 2007; Clarke et al., 2012) thus it might be worth investigating whether the photoperiodic variation in RFRP expression might also impact on food intake and body weight regulation in seasonal species.

\section{RFRP-3 MODES AND SITES OF ACTION}

The complex involvement of RFRP peptides in the regulation of the hypothalamic-pituitary-gonadal axis has raised a number of questions regarding the sites of action of the peptides. In various mammalian species including humans, RFRP fiber networks are found in multiple brain regions including the preoptic area, the arcuate nucleus, the lateral septum, the anterior hypothalamus, and the bed nucleus of the stria terminalis (Ukena and Tsutsui, 2001; Kriegsfeld et al., 2006; Johnson et al., 2007; Mason et al., 2010). Notably, RFRP-immunoreactive fibers make apparent contact with a subpopulation of GnRH neurons in rodents and sheep (Kriegsfeld et al., 2006; Smith et al., 2008; Poling et al., 2012; Rizwan et al., 2012; Ubuka et al., 2012) suggesting that RFRP-3 acts centrally to control the reproductive axis.

There is still uncertainty as to whether RFRP-3 also exerts a hypophysiotropic effect in mammals as reported in birds. A large body of evidence now reports the absence of fibers in the median eminence of rodents (Ukena and Tsutsui, 2001; Yano et al., 2003; Kriegsfeld et al., 2006; Rizwan et al., 2009; Smith et al., 2010; Ubuka et al., 2012). However, there are controversial data as to whether RFRP-3 acts (Kriegsfeld et al., 2006; Murakami et al., 2008; Pineda et al., 2010) or not (Anderson et al., 2009; Rizwan et al., 2009; Ubuka et al., 2012) on the rodent pituitary to regulate LH secretion. In the male hamster we reported no effect of the peptide on LH secretion when injected peripherally, nor on the basal and $\mathrm{GnRH}$-stimulated production of LH from isolated pituitary glands (Ancel et al., 2012). In contrast in the sheep, RFRP fibers terminating in the median eminence have been identified and the peptide is released into the portal blood and appears to induce a marked inhibition of gonadotropin secretion (Clarke et al., 2008; Sari et al., 2009; Smith et al., 2012).

The RFRP peptides bind with high affinity to GPR147 (also known as NPFF1R) and with a lower affinity to GPR74 (also known as NPFF2R), which were first identified as neuropeptide FF receptors (Hinuma et al., 2000; Liu et al., 2001; Engstrom et al., 2003). The GPR147 receptor couples with $\mathrm{G}_{\mathrm{i} 3}$ and $\mathrm{G}_{\alpha s}$ proteins (Gouarderes et al., 2007) suggesting that GPR147 can have both inhibitory and stimulatory downstream effects on cellular activity. However, in $\mathrm{CHO}$ cells, activation of the receptor inhibits forskolin-stimulated cAMP accumulation (Mollereau et al., 2002).

NPFF receptors have been detected in rodent, lagomorph, and monkey brains suggesting that they are phylogenetically conserved (Gouarderes et al., 2004a). Importantly, however, remarkable variations in GPR147 and GPR74 receptor contents exist from one species to another and from one strain to another among the same species (Gouarderes et al., 2004a,b). Early studies describing the autoradiographic distribution of GPR147 in mice and rats indicated that the receptor was present throughout the hypothalamus (Gouarderes et al., 2002, 2004a,b). More recently, the use of in situ hybridization facilitated precise localization and made it possible to show that about $25 \%$ of GnRH neurons express Gpr147, but not Gpr74, in various rodent species (Poling et al., 2012; Rizwan etal., 2012; Ubuka etal., 2012). This is in agreement with the observation that RFRP-3 fibers are in contact with $20-40 \%$ of GnRH neurons (Rizwan et al., 2012; Ubuka et al., 2012). Furthermore, in mice expressing $\mathrm{GnRH}$-green fluorescent protein-tagged neurons, RFRP-3 was found to exert a direct inhibitory effect on the firing rate of $41 \%$ of $\mathrm{GnRH}$ neurons, while $12 \%$ increased their firing rate, and the remainder were unaffected (Ducret et al., 2009). These observations support the hypothesis that RFRP-3 may exert its effects on reproduction directly via $\mathrm{GnRH}$ neurons. However, the peptide may also act indirectly, via upstream regulators of GnRH. This hypothesis is supported by data in rats indicating that RFRP-3 fibers are in contact with kisspeptin neurons, a subpopulation (20\%) of which expresses the Gpr147 gene (Rizwan et al., 2012).

In the Syrian hamster, RFRP-ir fibers project throughout much of the brain, including into the preoptic area and the arcuate nucleus (Kriegsfeld et al., 2006). We demonstrated that central injection of RFRP-3 to Syrian hamsters induces c-Fos expression in $30 \%$ of the GnRH neurons (Figure 2A) suggesting that the effects observed on the reproductive axis are mediated via these neurons (Ancel et al., 2012). Whether this effect is due to a direct action of RFRP-3 on GnRH neurons or whether it is linked to an effect on upstream regulators of the reproductive axis remains to be determined. Indeed, in the same study, although c-Fos expression was not observed in kisspeptin neurons following acute administration, the continuous central administration of RFRP-3 led to an increase in Kiss1 expression in the arcuate nucleus together with an increase of testicular activity (Figure 3; Ancel et al., 2012). It is therefore possible that the RFRP-3 neuronal system regulates reproductive activity by acting at two levels of the reproductive axis: the GnRH and the kisspeptin neurons. In order to answer this question, it seems essential to carry out a detailed mapping of the gpr147 in the Syrian hamster.

Altogether, a large amount of evidence now indicates that in various mammalian species RFRP-3 regulates reproductive activity by acting via its receptor located on $\mathrm{GnRH}$ neurons. This is supported by results showing that RFRP-3 fibers are in contact with a subpopulation of GnRH neurons and that Gpr147 is expressed in GnRH neurons in rodents. However, another line of evidence points to Kiss 1 neurons as possible intermediates between RFRP peptides and the regulation of the reproductive function. Indeed, in rats RFRP-3 fibers are in contact with kisspeptin neurons which express Gpr147 and in Syrian hamsters the reactivation of the reproductive function following continuous RFRP-3 administration goes alongside with an increase in Kiss 1 expression. Future studies using Kiss1R and GnRHR antagonists could help to understand the role of each one of these neuronal populations in mediating the effects of RFRP peptides on the reproductive axis. 


\section{RFRP-3 AND KISSPEPTIN ACT IN CONCERT TO SYNCHRONIZE RODENT REPRODUCTION WITH \\ THE SEASONS}

There is strong evidence that RFRP neurons are regulated by photoperiod/melatonin to adapt reproductive activity to the seasons. A few years ago, the same supposition was made for kisspeptin, another member of the large RFamide family of peptides. In 2003, milestone studies reported that loss-of-function mutations of the kisspeptin receptor (KiSS1R/GPR54) in humans and rodents (de Roux et al., 2003; Seminara et al., 2003) prevented pubertal development and caused infertility, leading to a large number of studies aiming at investigating the role of kisspeptins in Vertebrate reproduction (Pinilla et al., 2012 for review). The Kiss 1 gene is mainly expressed in the arcuate nucleus and the anteroventro-periventricular nucleus of the hypothalamus, and kisspeptin neurons project specifically onto the GnRH cell bodies in the preoptic area and nerve terminals in the median eminence. In all mammalian species studied to date, kisspeptin appears as a powerful stimulator of the gonadotropic axis, acting primarily on GnRH neurons.

In the male Syrian hamster, we demonstrated that kisspeptin expression in the arcuate nucleus is down-regulated by melatonin in SD conditions, despite a negative feedback effect of testosterone on these neurons (Revel etal., 2006b). In the anteroventroperiventricular nucleus, kisspeptin expression is also decrease in SD conditions, but as a result of the absence of the positive feedback of testosterone consecutive to testicular regression (Ansel et al., 2010). Importantly, we demonstrated that chronic infusion of kisspeptin in SD-adapted sexually inactive male hamsters rescues reproductive activity to levels comparable to animals kept in photo-stimulatory LD conditions (Revel et al., 2006b; Ansel et al., 2011; Simonneaux et al., 2012). In the Siberian hamster as well, kisspeptin expression displays photoperiod variations and the peptide stimulates LH release (Greives et al., 2008a,b). Interestingly in the sheep, kisspeptin expression is also regulated by photoperiod, with a higher level of expression in SD conditions when animals are sexually active, and kisspeptin infusion in LD-adapted anestrous ewes induces ovulation in a majority of treated animals (Franceschini etal., 2006; Caraty et al., 2007; Smith et al., 2007, 2009). These observations indicate that kisspeptin expression, like RFRP, is regulated by photoperiod in seasonal species but, unlike RFRP, the direction of the regulation is different according to whether animals are LD- or SD-breeders.

To make things more complicated, other parameters also influenced by seasons regulate kisspeptin expression. This is particularly true for sex steroids which inhibit kisspeptin expression in the arcuate nucleus and increase it in the anteroventroperiventricular nucleus in various species including the Syrian (Revel etal., 2006b; Ansel et al., 2010) and the Siberian (Mason et al., 2007) hamsters. Additionally, metabolic factors that are also under the influence of seasonal changes were shown to impact on kisspeptin expression (Castellano et al., 2010). Therefore, although kisspeptin has been identified as an essential component of the photoperiodic regulation of reproductive activity in seasonal breeders (Revel etal., 2007; Simonneaux et al., 2009, 2012 for reviews) recent observations indicate that kisspeptin neurons are not the primary target of melatonin action but are controlled upstream by seasonally regulated intermediates.

Our current findings in the Syrian, Siberian, and European hamsters (Revel et al., 2008; Figure 1), in the jerboa (Janati et al., 2012), and other reports in the sheep (Dardente et al., 2008; Smith et al., 2008) suggest that RFRP-3 expression undergoes a conserved down-regulation by the SD melatonin signal irrespective of the reproductive response to seasons. In contrast, kisspeptin expression is increased when animals become sexually active, irrespective of the photoperiod. On the other hand, kisspeptin is always stimulatory of reproductive activity whereas RFRP-3 displays species-specific effects, being stimulatory in the Syrian hamster and inhibitory in the sheep.

These observations have led us to propose a working model for the seasonal control of reproduction in rodents (Figure 4). We propose that in LD conditions, RFRP-3 would activate $\mathrm{GnRH}$ neuronal activity directly and/or indirectly via the kisspeptinergic neurons. The former pathway is supported by the report of RFRP-3 fibers apposed to subpopulations of GnRH neurons (Kriegsfeld et al., 2006) whereas the latter

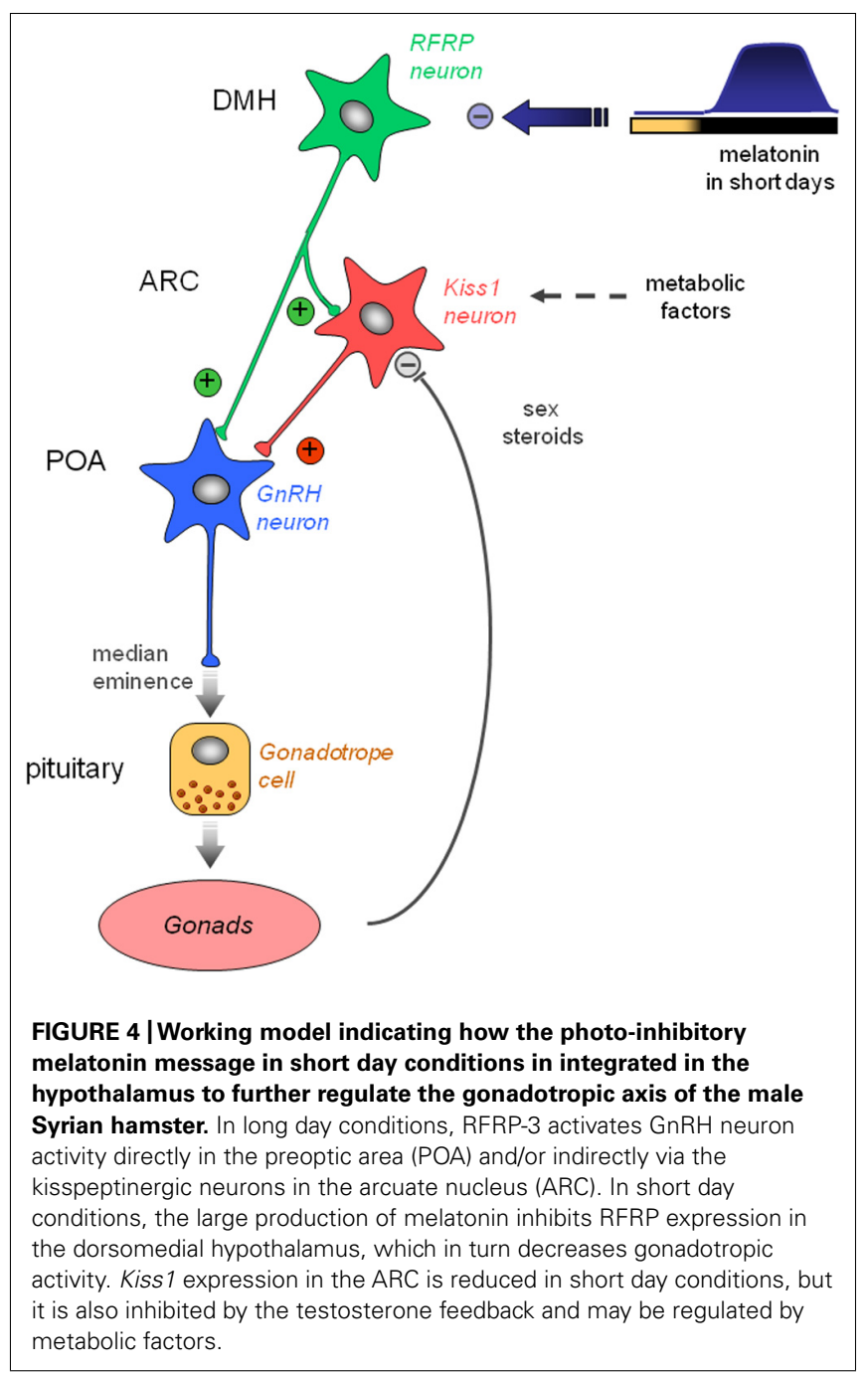


is supported both by a report in rats indicating that RFRP-3 fibers are in contact with subpopulations of kisspeptin neurons (Rizwan et al., 2012) and by our observation that chronic central infusion of RFRP-3 increases arcuate Kiss1 expression together with a reactivation of testicular function in the Syrian hamster (Ancel et al., 2012). In SD conditions, the melatoninergic signal would be primarily integrated by the hypothalamic RFRP neurons leading to a decreased expression of the peptide, but whether melatonin acts directly or not on RFRP neurons has yet to be determined. Current studies do not support a major feedback effect of sex steroids on RFRP neurons. In contrast, kisspeptinergic neurons integrate other factors related to the sexual and metabolic status of the animal in order to finely tune reproductive activity with the seasons. From studies in sheep, a SD-breeder, it appears that an increased production of RFRP-3 in LD conditions would inhibit reproductive activity by acting directly on the GnRH neurons and/or on the pituitary (Smith et al., 2008; Sari et al., 2009).

\section{REFERENCES}

Ancel, C., Bentsen, A. H., Sebert, M. E., Tena-Sempere, M., Mikkelsen, J. D., and Simonneaux, V. (2012). Stimulatory effect of RFRP-3 on the gonadotrophic axis in the male Syrian hamster: the exception proves the rule. Endocrinology 153, 1352 1363.

Anderson, G. M., Relf, H. L., Rizwan, M. Z., and Evans, J. J. (2009). Central and peripheral effects of RFamiderelated peptide- 3 on luteinizing hormone and prolactin secretion in rats. Endocrinology 150, 1834-1840.

Ansel, L., Bentsen, A. H., Ancel, C., Bolborea, M., Klosen, P., Mikkelsen, J. D., et al. (2011). Peripheral kisspeptin reverses short photoperiod-induced gonadal regression in Syrian hamsters by promoting GnRH release. Reproduction 142, 417-425.

Ansel, L., Bolborea, M., Bentsen, A. H., Klosen, P., Mikkelsen, J. D., and Simonneaux V. (2010). Differential regulation of kiss1 expression by melatonin and gonadal hormones in male and female Syrian hamsters. J. Biol. Rhythms 25, 81-91.

Barrett, P., Ebling, F. J., Schuhler, S., Wilson, D., Ross, A. W., Warner, A., et al. (2007). Hypothalamic thyroid hormone catabolism acts as a gatekeeper for the seasonal control of body weight and reproduction. Endocrinology 148, 3608-3617.

Bartness, T. J., Powers, J. B., Hastings, M. H., Bittman, E. L., and Goldman, B. D. (1993). The timed infusion paradigm for melatonin delivery: what has it taught us about the melatonin signal, its reception, and the photoperiodic control of seasonal responses? J. Pineal Res. 15, 161-190.
Bechtold, D. A., and Luckman, S. M. (2007). The role of RFamide peptides in feeding. J. Endocrinol. 192, 3-15.

Bentley, G. E., Tsutsui, K., and Kriegsfeld, L. J. (2010). Recent studies of gonadotropin-inhibitory hormone $(\mathrm{GnIH})$ in the mammalian hypothalamus, pituitary and gonads. Brain Res. 1364, 62-71.

Caraty, A., Blomenröhr, M., Vogel, G. M., Lomet, D., Briant, C., and Beltramo, M. (2012). RF9 powerfully stimulates gonadotrophin secretion in the ewe: evidence for a seasonal threshold of sensitivity. J. Neuroen-

Caraty, A., Smith, J. T., Lomet, D., Ben Said, S., Morrissey, A., Cognie, J., et al. (2007). Kisspeptin synchronizes preovulatory surges in cyclical ewes and causes ovulation in seasonally acyclic ewes. Endocrinology 148, 52585267.

Carter, D. S., and Goldman, B. D. (1983). Antigonadal effects of timed melatonin infusion in pinealectomized male Djungarian hamsters (Phodopus sungorus sungorus): duration is the critical parameter. Endocrinology 113, 1261-1267.

Castellano, J. M., Bentsen, A. H. Mikkelsen, J. D., and Tena-Sempere, M. (2010). Kisspeptins: bridging energy homeostasis and reproduction. Brain Res. 1364, 129-138.

Clarke, I. J., Sari, I. P., Qi, Y., Smith, J. T., Parkington, H. C., Ubuka, T., etal. (2008). Potent action of RFamide-related peptide- 3 on pituitary gonadotropes indicative of a hypophysiotropic role in the negative regulation of gonadotropin secretion. Endocrinology 149, 5811-5821.

Clarke, I. J., Smith, J. T., Henry, B. A., Oldfield, B. J., Stefanidis, docrinol. 24, 725-736.

\section{CONCLUSION}

In regard to the seasonal regulation of reproductive activity, recent data have shed light on the involvement of two hypothalamic peptides of the RFamide family, RFRP-3 and kisspeptin. Clearly both peptides are regulated by the photoperiodic melatoninergic signal but may also be sensitive to other seasonally regulated factors. Our current hypothesis is that RFRP expression undergoes a conserved inhibition in short photoperiod but the peptide may be stimulatory or inhibitory according to the reproductive physiology of the species; on the other hand, kisspeptin has a conserved stimulatory action on the gonadotropic axis but its seasonal regulation shows species differences. Whether RFRP-3 and kisspeptin act on each other's expression or independently to regulate reproductive activity has yet to be clarified in different species. In the years to come, we believe that thorough comparative analyses on the effects and sites of action of both peptides between LD- and SD-breeders should help to resolve the yet unanswered question of why the same photoperiodic cue induces opposite behavioral responses.

A., Millar, R. P., et al. (2012). Gonadotropin-inhibitory hormone is a hypothalamic peptide that provides a molecular switch between reproduction and feeding. Neuroen docrinology 95, 305-316.

Dardente, H. (2012). Melatonindependent timing of seasonal reproduction by the pars tuberalis: pivotal roles for long daylengths and thyroid hormones. J. Neuroendocrinol. 24, 249-266

Dardente, H., Birnie, M., Lincoln, G. A., and Hazlerigg, D. G. (2008) RFamide-related peptide and its cognate receptor in the sheep: cDNA cloning, mRNA distribution in the hypothalamus and the effect of photoperiod. J. Neuroendocrinol. 20 1252-1259.

Dardente, H., Klosen, P., Pevet, P., and Masson-Pevet, M. (2003). MT1 melatonin receptor mRNA expressing cells in the pars tuberalis of the European hamster: effect of photoperiod. J. Neuroendocrinol. 15, 778-786.

Dardente, H., Wyse, C. A., Birnie, M. J., Dupre, S. M., Loudon, A. S., Lincoln, G. A., et al. (2010). A molecular switch for photoperiod responsiveness in mammals. Curr. Biol. 20, 2193-2198.

de Roux, N., Genin, E., Carel, J. C. Matsuda, F., Chaussain, J. L., and Milgrom, E. (2003). Hypogonadotropic hypogonadism due to loss of function of the KiSS1-derived peptide receptor GPR54. Proc. Natl. Acad. Sci. U.S.A 100, 10972-10976.

Ducret, E., Anderson, G. M., and Herbison, A. E. (2009). RFamiderelated peptide-3, a mammalian gonadotropin-inhibitory hormone ortholog, regulates gonadotropinreleasing hormone neuron firing in the mouse. Endocrinology 150, 2799-2804.

Engstrom, M., Brandt, A., Wurster, S., Savola, J. M., and Panula, P. (2003). Prolactin releasing peptide has high affinity and efficacy at neuropeptide FF2 receptors. J. Pharmacol. Exp. Ther. 305, 825-832.

Franceschini, I., Lomet, D., Cateau, M., Delsol, G., Tillet, Y., and Caraty, A. (2006). Kisspeptin immunoreactive cells of the ovine preoptic area and arcuate nucleus co-express estrogen receptor alpha. Neurosci. Lett. 401, 225-230.

Gibson, E. M., Humber, S. A., Jain, S., Williams, W. P. III, Zhao, S., Bentley, G. E., et al. (2008). Alterations in RFamide-related peptide expression are coordinated with the preovulatory luteinizing hormone surge. Endocrinology 149, 4958-4969.

Gouarderes, C., Mazarguil, H., Mollereau, C., Chartrel, N., Leprince, J., Vaudry, H., et al. (2007). Functional differences between NPFF1 and NPFF2 receptor coupling: high intrinsic activities of RFamide-related peptides on stimulation of [35S] GTPgammaS binding. Neuropharmacology 52, 376-386.

Gouarderes, C., Puget, A., and Zajac, J. M. (2004a). Detailed distribution of neuropeptide FF receptors (NPFF1 and NPFF2) in the rat, mouse, octodon, rabbit, guinea pig, and marmoset monkey brains: a comparative autoradiographic study. Synapse 51, 249-269.

Gouarderes, C., Faura, C. C., and Zajac, J. M. (2004b). Rodent strain differences in the NPFF1 and NPFF2 receptor distribution and density in the central nervous system. Brain Res. 1014, 61-70. 
Gouarderes, C., Quelven, I., Mollereau, C., Mazarguil, H., Rice, S. Q., and Zajac, J. M. (2002). Quantitative autoradiographic distribution of NPFF1 neuropeptide FF receptor in the rat brain and comparison with NPFF2 receptor by using [125I]YVP and [(125I]EYF as selective radioligands. Neuroscience 115, 349-361.

Greives, T. J., Humber, S. A., Goldstein, A. N., Scotti, M. A., Demas, G. E., and Kriegsfeld, L. J. (2008a). Photoperiod and testosterone interact to drive seasonal changes in kisspeptin expression in Siberian hamsters (Phodopus sungorus). J. Neuroendocrinol. 20, 1339-1347.

Greives, T. J., Kriegsfeld, L. J., and Demas, G. E. (2008b). Exogenous kisspeptin does not alter photoperiod-induced gonadal regression in Siberian hamsters (Phodopus sungorus). Gen. Comp. Endocrinol. 156, 552-558.

Hanon, E. A., Lincoln, G. A., Fustin, J. M., Dardente, H., Masson-Pevet, M., Morgan, P. J., et al. (2008). Ancestral TSH mechanism signals summer in a photoperiodic mammal. Curr. Biol. $18,1147-1152$.

Hanon, E. A., Routledge, K., Dardente, H., Masson-Pevet, M., Morgan, P. J., and Hazlerigg, D. G. (2010). Effect of photoperiod on the thyroid-stimulating hormone neuroendocrine system in the European hamster (Cricetus cricetus). J. Neuroendocrinol. 22, 51-55.

Hinuma, S., Shintani, Y., Fukusumi, S., Iijima, N., Matsumoto, Y., Hosoya, M., etal. (2000). New neuropeptides containing carboxyterminal RFamide and their receptor in mammals. Nat. Cell Biol. 2, 703-708.

Hoffman, R. A., and Reiter, R. J. (1965). Pineal gland: influence on gonads of male hamsters. Science 148, 16091611.

Janati, A., Talbi, R., Klosen, P., Mikkelsen, J., Magoul, R., Simonneaux, V., et al. (2012). Distribution and seasonal variation in hypothalamic RF-amide peptides in a semidesert rodent, the jerboa. J. Neuroendocrinol. (in press).

Johnson, M. A., Tsutsui, K., and Fraley, G. S. (2007). Rat RFamide-related peptide-3 stimulates GH secretion, inhibits LH secretion, and has variable effects on sex behavior in the adult male rat. Horm. Behav. 51, 171-180.

Kadokawa, H., Shibata, M., Tanaka, Y., Kojima, T., Matsumoto, K., Oshima, K., et al. (2009). Bovine C-terminal octapeptide of RFamide-related peptide-3 suppresses luteinizing hormone (LH) secretion from the pituitary as well as pulsatile $\mathrm{LH}$ secretion in bovines. Domest. Anim. Endocrinol. 36, 219-224.

Klosen, P., Bienvenu, C., Demarteau O., Dardente, H., Guerrero, H. Pevet, P., etal. (2002). The mtl melatonin receptor and RORbeta receptor are co-localized in specific TSH-immunoreactive cells in the pars tuberalis of the rat pituitary. J. Histochem. Cytochem. 50, 16471657.

Kriegsfeld, L. J., Gibson, E. M., Williams, W. P. III, Zhao, S., Mason, A. O., Bentley, G. E., et al. (2010). The roles of RFamide-related peptide- 3 in mammalian reproductive function and behaviour. J. Neuroendocrinol. 22, 692-700.

Kriegsfeld, L. J., Mei, D. F., Bentley, G. E., Ubuka, T., Mason, A. O., Inoue K., et al. (2006). Identification and characterization of a gonadotropininhibitory system in the brains of mammals. Proc. Natl. Acad. Sci. U.S.A. 103, 2410-2415

Liu, Q., Guan, X. M., Martin, W. J., McDonald, T. P., Clements, M. K. Jiang, Q., et al. (2001). Identification and characterization of novel mammalian neuropeptide FF-like peptides that attenuate morphineinduced antinociception. J. Biol. Chem. 276, 36961-36969.

Malpaux, B., Daveau, A., MauriceMandon, F., Duarte, G., and Chemineau, P. (1998). Evidence that melatonin acts in the premammillary hypothalamic area to control reproduction in the ewe: presence of binding sites and stimulation of luteinizing hormone secretion by in situ microimplant delivery. Endocrinology 139, 1508-1516.

Malpaux, B., Migaud, M., Tricoire, H., and Chemineau, P. (2001). Biology of mammalian photoperiodism and the critical role of the pineal gland and melatonin. J. Biol. Rhythms 16, 336-347.

Mason, A. O., Duffy, S., Zhao, S., Ubuka, T., Bentley, G. E., Tsutsui, K., et al. (2010). Photoperiod and reproductive condition are associated with changes in RFamide-related peptide (RFRP) expression in Syrian hamsters (Mesocricetus auratus). J. Biol. Rhythms 25, 176-185.

Mason, A. O., Greives, T. J., Scotti, M. A., Levine, J., Frommeyer, S., Ketterson, E. D., et al. (2007). Suppression of kisspeptin expression and gonadotropic axis sensitivity following exposure to inhibitory day lengths in female Siberian hamsters. Horm. Behav. 52, 492-498.
Masson-Pevet, M., and Gauer, F. (1994). Seasonality and melatonin receptors in the pars tuberalis in some long day breeders. Biol. Signals 3, 63-70.

Masson-Pevet, M., George, D., Kalsbeek, A., Saboureau, M., LakhdarGhazal, N., and Pevet, P. (1994). An attempt to correlate brain areas containing melatonin-binding sites with rhythmic functions: a study in five hibernator species. Cell Tissue Res. 278, 97-106.

Maywood, E. S., Bittman, E. L., and Hastings, M. H. (1996). Lesions of the melatonin- and androgen-responsive tissue of the dorsomedial nucleus of the hypothalamus block the gonadal response of male Syrian hamsters to programmed infusions of melatonin. Biol. Reprod. 54, 470-477.

Maywood, E. S., and Hastings, M. H. (1995). Lesions of the iodomelatonin-binding sites of the mediobasal hypothalamus spare the lactotropic, but block the gonadotropic response of male Syrian hamsters to short photoperiod and to melatonin. Endocrinology 136, 144-153.

Mollereau, C., Mazarguil, H., Marcus, D., Quelven, I., Kotani, M., Lannoy, V., et al. (2002). Pharmacological characterization of human $\operatorname{NPFF}(1)$ and $\operatorname{NPFF}(2)$ receptors expressed in CHO cells by using NPY Y(1) receptor antagonists. Eur. J. Pharmacol. 451, 245-256.

Murakami, M., Matsuzaki, T., Iwasa, T., Yasui, T., Irahara, M., Osugi, T. et al. (2008). Hypophysiotropic role of RFamide-related peptide- 3 in the inhibition of LH secretion in female rats. J. Endocrinol. 199, 105-112.

Nakao, N., Ono, H., Yamamura, T., Anraku, T., Takagi, T., Higashi, K., et al. (2008). Thyrotrophin in the pars tuberalis triggers photoperiodic response. Nature 452, 317-322.

Pevet, P. (1988). The role of the pineal gland in the photoperiodic control of reproduction in different hamster species. Reprod. Nutr. Dev. 28 , 443-458.

Pineda, R., Garcia-Galiano, D., Sanchez-Garrido, M. A., Romero, M., Ruiz-Pino, F., Aguilar, E., et al. (2010). Characterization of the inhibitory roles of RFRP3, the mammalian ortholog of $\mathrm{GnIH}$, in the control of gonadotropin secretion in the rat: in vivo and in vitro studies. Am. J. Physiol. Endocrinol. Metab. 299, E39-E46.

Pinilla, L., Aguilar, E., Dieguez, C., Millar, R. P., and Tena-Sempere, M. (2012). Kisspeptins and reproduction: physiological roles and regulatory mechanisms. Physiol. Rev. 92, 1235-1316.

Poling, M. C., Kim, J., Dhamija, S., and Kauffman, A. S. (2012). Development, sex steroid regulation, and phenotypic characterization of RFamide-related peptide (Rfrp) gene expression and RFamide receptors in the mouse hypothalamus. Endocrinology 153, 1827-1840.

Quennell, J. H., Rizwan, M. Z., Relf, H. L., and Anderson, G. M. (2010). Developmental and steroidogenic effects on the gene expression of RFamide related peptides and their receptor in the rat brain and pituitary gland. J. Neuroendocrinol. 22, 309-316.

Revel, F. G., Ansel, L., Klosen, P., Saboureau, M., Pevet, P., Mikkelsen, J. D., et al. (2007). Kisspeptin: a key link to seasonal breeding. Rev. Endocr. Metab. Disord. 8, 57-65.

Revel, F. G., Saboureau, M., Pevet, P., Mikkelsen, J. D., and Simonneaux, V. (2006a). Melatonin regulates type 2 deiodinase gene expression in the Syrian hamster. Endocrinology 147, 4680-4687.

Revel, F. G., Saboureau, M., MassonPevet, M., Pevet, P., Mikkelsen, J. D., and Simonneaux, V. (2006b). Kisspeptin mediates the photoperiodic control of reproduction in hamsters. Curr. Biol. 16, 1730-1735.

Revel, F. G., Saboureau, M., Pevet, P., Simonneaux, V., and Mikkelsen, J. D. (2008). RFamide-related peptide gene is a melatonin-driven photoperiodic gene. Endocrinology 149, 902-912.

Rizwan, M. Z., Poling, M. C., Corr, M., Cornes, P. A., Augustine, R. A., Quennell, J. H., etal. (2012). RFamide-related peptide-3 receptor gene expression in $\mathrm{GnRH}$ and kisspeptin neurons and GnRHdependent mechanism of action. Endocrinology 153, 3770-3779.

Rizwan, M. Z., Porteous, R., Herbison, A. E., and Anderson, G. M. (2009). Cells expressing RFamiderelated peptide-1/3, the mammalian gonadotropin-inhibitory hormone orthologs, are not hypophysiotropic neuroendocrine neurons in the rat. Endocrinology 150, 1413-1420.

Sari, I. P., Rao, A., Smith, J. T., Tilbrook, A. J., and Clarke, I. J. (2009). Effect of RF-amide-related peptide3 on luteinizing hormone and follicle-stimulating hormone synthesis and secretion in ovine pituitary gonadotropes. Endocrinology 150, 5549-5556.

Seminara, S. B., Messager, S., Chatzidaki, E. E., Thresher, R. R., Acierno, J. S., Shagoury, J. K., et al. (2003). The 
GPR54 gene as a regulator of puberty. N. Engl. J. Med. 349, 1614-1627.

Simonneaux, V., Ansel, L., Revel, F. G., Klosen, P., Pevet, P., and Mikkelsen, J. D. (2009). Kisspeptin and the seasonal control of reproduction in hamsters. Peptides 30, 146-153.

Simonneaux, V., Bur, I., Ancel, C., Ansel, L., and Klosen, P. (2012). A kiss for daily and seasonal reproduction. Prog. Brain Res. 199, 423-437.

Simonneaux, V., and Ribelayga, C. (2003). Generation of the melatonin endocrine message in mammals: a review of the complex regulation of melatonin synthesis by norepinephrine, peptides, and other pineal transmitters. Pharmacol. Rev. 55, 325-395.

Smith, J. T., Clay, C. M., Caraty, A., and Clarke, I. J. (2007). KiSS-1 messenger ribonucleic acid expression in the hypothalamus of the ewe is regulated by sex steroids and season. Endocrinology 148, 1150-1157.

Smith, J. T., Saleh, S. N., and Clarke, I. J. (2009). Seasonal and cyclical change in the luteinizing hormone response to kisspeptin in the ewe. Neuroendocrinology 90, 283-291.

Smith, J. T., Shahab, M., Pereira, A., Pau, K. Y., and Clarke, I. J. (2010). Hypothalamic expression of KISS1 and gonadotropin inhibitory hormone genes during the menstrual cycle of a non-human primate. Biol. Reprod. 83, 568-577.
Smith, J. T., Young, I. R., Veldhuis, J. D., and Clarke, I. J. (2012). Gonadotropin-inhibitory hormone $(\mathrm{GnIH})$ secretion into the ovine hypophyseal portal system. Endocrinology 153, 33683375.

Smith, J. T., and Clarke, I. J. (2010). Gonadotropin inhibitory hormone function in mammals. Trends Endocrinol. Metab. 21, 255260.

Smith, J. T., Coolen, L. M., Kriegsfeld, L. J., Sari, I. P., Jaafarzadehshirazi, M. R., Maltby, M., et al. (2008). Variation in kisspeptin and RFamide-related peptide (RFRP) expression and terminal connections to gonadotropinreleasing hormone neurons in the brain: a novel medium for seasonal breeding in the sheep. Endocrinology 149, 5770-5782.

Tsutsui, K., Bentley, G. E., Bedecarrats, G., Osugi, T., Ubuka, T., and Kriegsfeld, L. J. (2010). Gonadotropininhibitory hormone $(\mathrm{GnIH})$ and its control of central and peripheral reproductive function. Front. Neuroendocrinol. 31:284-295. doi: 10.1016/j.yfrne.2010.03.001

Tsutsui, K., Saigoh, E., Ukena, K., Teranishi, H., Fujisawa, Y., Kikuchi, M., etal. (2000). A novel avian hypothalamic peptide inhibiting gonadotropin release. Biochem. Biophys. Res. Commun. 275, 661-667.
Ubuka, T., Bentley, G. E., Ukena, K., Wingfield, J. C., and Tsutsui, K. (2005). Melatonin induces the expression of gonadotropininhibitory hormone in the avian brain. Proc. Natl. Acad. Sci. U.S.A. 102, 3052-3057.

Ubuka, T., Inoue, K., Fukuda, Y., Mizuno, T., Ukena, K., Kriegsfeld, L. J., et al. (2012). Identification, expression, and physiological functions of Siberian hamster gonadotropininhibitory hormone. Endocrinology 153, 373-385.

Ukena, K., and Tsutsui, K. (2001). Distribution of novel RFamide-related peptide-like immunoreactivity in the mouse central nervous system. Neurosci. Lett. 300, 153-156.

Urbanski, H. F., Doan, A., and Pierce, M. (1991). Immunocytochemical investigation of luteinizing hormonereleasing hormone neurons in Syrian hamsters maintained under long or short days. Biol. Reprod. 44, 687-692.

Yano, T., Iijima, N., Kakihara, K., Hinuma, S., Tanaka, M., and Ibata, Y. (2003). Localization and neuronal response of RFamide related peptides in the rat central nervous system. Brain Res. 982, 156-167.

Yasuo, S., Yoshimura, T., Ebihara, S., and Korf, H. W. (2007). Temporal dynamics of type 2 deiodinase expression after melatonin injections in Syrian hamsters. Endocrinology 148, 43854392 .
Yoshimura, T., Yasuo, S., Watanabe, M., Iigo, M., Yamamura, T., Hirunagi, K., et al. (2003). Lightinduced hormone conversion of $\mathrm{T} 4$ to T3 regulates photoperiodic response of gonads in birds. Nature 426, 178-181.

Conflict of Interest Statement: The authors declare that the research was conducted in the absence of any commercial or financial relationships that could be construed as a potential conflict of interest.

Received: 15 October 2012; paperpending published: 11 November 2012; accepted: 04 December 2012; published online: 18 December 2012.

Citation: Simonneaux $V$ and Ancel $C$ (2012) RFRP neurons are critical gatekeepers for the photoperiodic control of reproduction. Front. Endocrin. 3:168. doi: 10.3389/fendo.2012.00168

This article was submitted to Frontiers in Neuroendocrine Science, a specialty of Frontiers in Endocrinology.

Copyright (c) 2012 Simonneaux and Ancel. This is an open-access article distributed under the terms of the Creative Commons Attribution License, which permits use, distribution and reproduction in other forums, provided the original authors and source are credited and subject to any copyright notices concerning any third-party graphics etc. 